\title{
THE POWER OF STORY IN AN ANIMATION INDUSTRY
}

\author{
Kadek Satria Adidharma \\ Jurusan Desain Komunikasi Visual, Fakultas Komunikasi dan Multimedia, BINUS University \\ Jln. K.H. Syahdan No. 9, Kemanggisan, Palmerah, Jakarta Barat 11480 \\ satria23@gmail.com
}

\begin{abstract}
After the founding of the Walt Disney Company, animation becomes something necessary in our everyday life. The real power why the animation bigger is the storytelling. Story is the main key why animation is loveable by audiences. This writing will be focusing on the behind reason why the story is important in animation and will be giving some examples the success story of some animation which have a great story to tell. The design methodology focuses on data research, market research and literature book. This writing is a preliminary research because from the author concern, there are not many writings debating whether which part in the development will be focused on to developing some animation projects. This writing hopefully will help people who want to build some animation projects and will guide them to make decision because in order to build some animation project there will be a massive effort to be conducted. Hopefully, in the future, there will be more animation produced from Indonesian. To be an unforgettable work, it must have a great story.
\end{abstract}

Keywords: story, animation

\begin{abstract}
ABSTRAK
Setelah penemuan oleh Walt Disney, animasi menjadi sesuatu yang penting dalam kehidupan kita sehari-hari. Kekuatan terkuat kenapa animasi menjadi besar adalah storytelling. Cerita adalah kunci utama animasi bisa dicintai oleh audiens. Tulisan ini akan membahas tentang alasan kenapa cerita menjadi penting dalam animasi dan akan memberikan contoh-contoh animasi yang memiliki cerita sukses. Metode pembahasan tulisan ini yaitu penelitian data, market, dan literatur. Tulisan ini adalah penelitian awal karena penulis meyakini bahwa tidak banyak tulisan yang membahas tentang fokus pengembangan proyek animasi. Tulisan ini diharapkan akan membantu mereka yang ingin mengembangkan proyek animasi dan membimbing mereka untuk membuat putusan karena membuat proyek animasi akan membutuhkan usaha yang kuat. Diharapkan, di masa mendatang, akan lebih banyak animasi diproduksi oleh orang Indonesia. Untuk menjadi hasil karya tak terlupakan, harus memiliki cerita yang bagus.
\end{abstract}

Kata kunci: cerita, animasi 


\section{INTRODUCTION}

In $21^{\text {st }}$ century, after the founding of the Walt Disney Company, animation is become something necessary in our everyday life. Starting from a new technology of motion pictures to become an entertainment that everybody needs, both kids and adults. Thanks to Disney family, animation is now become one of the most respected field in the entertainment business. Respected because it gives a different perspective and it gives something that conventional method can not be given. The use of technology is one of the selling points of animation. From stop motion pictures to three dimensional projections, animation can stun everybody's eye through its technologies.

But despite of the development and the creation of its technology, we sometimes forgot that the real power of animation is not the technology. The real power why the animation is bigger than we realize is the storytelling. Story is the main key why animation is loveable by the audiences. Story is the main generator to boosting up sales, to driving up everybody's attention. Although the latest technology is a must for produce some animation, it will be useless if the animation doesn't have a great or twisted story. There are many examples that story is everything. From Pixar's creations, Nickelodeon's which touches our everyday life by its daily television animation series. Until the Asians, especially Japan animation that we used to call it anime.

This writing will be focusing on the behind reason why the story is important in animation and will be giving some examples the success story of some animation which have a great story to tell. The Design Methodology will be focusing on data research, market research and book literature. Data and market research are compulsory because through the research we will know the reasons why most of the audience is mainly like the animation from the story first rather than any other factor such as technologies, actors, directors and some other reasons.

This writing is a preliminary research because from the author concern, there are not many writings debating whether which part in the development will be focused on to developing some animation projects. This writing hopefully will help people who want to build some animation projects and will be guide them to make some decision because to build some animation project there will be a massive effort to conduct.

\section{METHOD}

The methodology to conduct this writing are books literature, data research and market research. The data will be collected from many resources such as articles on magazine, articles and news from reputable websites, and some statistics and facts that will be collected from internet as well. The book literature is needed as a foundation to make an opinion to become more objectives. The literature only revolves in a background reason to support the author statement. Data figures will be divided by country region to break down the creation with its facts in different country.

\section{DISCUSSION}

This writing will be divided by region to make readers easier to follow the authors point of view. The author will divide the region by International Market which are United States of America, European Country and United Kingdom. Then the other region is Asia Market as in Japan and South East Asia. Lastly, the author will be defining the Local Trends, how and why some animations were famous in Indonesia. 
Story is many filmmakers would agree is the most powerful element in movie industry. Although majority people would agree, but we also know that movie industry is not a scientific field that we can measured everything. Nobody knows what the certainty in this business is. This is similar when we talk about the animation industry. The animation industry is has no different from the movie industry. It is only a slight different from the movie industry because some technology is required to create some animated sequence. Not only a technology to animate sequence is required but it needs lots of drawing and storytelling. That is why there are some debate appears when we want to create some animation projects. What is the most important element to create a great animation? Whether is the story, the character design, or what kind of technology it used?

Before the Three Dimension is becoming popular, animation is created by Two Dimensional imagery either from capturing tons of drawing images or capture tons of action pose which we called the technique a Stop Motion. Stop Motion is used to be a numero uno technology before the 3D appeared. Lots of Hollywood produced movie used this technique to support the visual effect. But there are some drawbacks with these techniques. One of the major problem is it is need a lot of working hours. Approximately, to make a minute sequences, its need at least 10 animators and a month of working hour. That is why several years back then; two-dimensional animation by capturing photographic sequences is more popular.

But today, after more than twenty years of development, Three Dimensional Imagery was becoming more popular because it can gives more realistic images and it needs less working hour compare to the Two Dimensional Imagery. Especially in 1998, there was a full length animation movie produced by Pixar called Toy Story appeared. At that time, the studio still needs lots of working hour. For the Toy Story success until premiered on to the cinema, the team needed at least 4 years of development. But after the years of improvement of the 3D technology, the working hours can be cut by half and nowadays, approximately a full length animation movie can be produce by two years only.

That is why in this transition era, there are some debate appears whether we use the latest technology or not to produce our animation. But the debate is not just stop on using 2D or 3D technique. It grows to something more ridiculous. Some stated that several software are better than others. Several Textures, Rigging, Model, and others are better. They were forgotten the most crucial aspect in creating some moving images. They forgot that the story is everything.

Some facts are true that story can make some animation remembered and timeless. Some facts also is giving a proof that technology only make it better or even make it worst. We began to analyze it by looking the facts that happen in the Northern America. Both in a full length animation or television industry, there are some proving that there were no guarantee if we use the $3 \mathrm{D}$ techniques will make our animation better.

In television production there were some phenomena where 2D is more famous than the 3D. The best practice on this field is the Nickelodeon. Nickelodeon is aired some of the famous television series such as Dora the Explorer, Spongebob Squarepants and the newest hype, the Phineas and Ferb. Most of these animation used the conventional techniques, which is the two dimensional imagery. In some sequence, they used some three dimensional imagery to support the story or to make the production easier. Although some of Nickelodeon program is based on three-dimensional imagery such as the Penguin of Madagascar, but its still selling the product by its story not by its use of some kind of software.

Why this program is becoming popular, the answer is simple. The story is behind it. For example the Spongebob Squarepants which becomes phenomenal in the last decade because the story is giving something different. The audience that have been targeted is various from adult to children. The adult likes it because of the story telling is different from other series. Sometimes it is using some terminology that the adult still enjoying it. Children like it because of the uniqueness of character 
design, but also the character teaches them in a different way. The old paradigm about teaching kids not to do some inappropriate behavior is visualized differently by Spongebob Squarepants. The Phineas and Ferb is another story but similar success. The Phineas and Ferb is the latest installment produced by Nickelodeon. This program is really touches every children's dream. It tells two brothers who have become an alpha geek in their early age. They create something scientific but unimaginable, beyond what we expected. But the twisted part is, their parents is never know what are their truly capabilities. Only their sister is trying so hard to prove the parents is wrong. This model of story is brilliant and proportional for kids who grown up by their dreams (Edwards, 2010). Kids at a certain age are always having some dream that has no boundaries. A dream that for an adult person is never can be understood why they bother enough to think something that we used to say impossible. But that is the power of kids dream. The Phineas and Ferb is an animation program that can represent and visualize their dream.

Another phenomenon that already appeared more than a decade ago is a trend that happened in television industry. Two decades ago, there were some category appeared in television industry in Northern America. The category is PG-rated Animation. One of the phenomenal television series and is still is until now is The Simpsons created by Matt Groening. At that time, people were mocking its visual style because the style is more like a kids drawing. There were no professional skills needed. But despite of its drawing, the story is tremendous. People are laugh out loud when they watched it. The Simpsons is become phenomenal because the storytelling is really different not just compare by the other animation program, but by general television program as well (Garisson, 2001). It is telling some story that in some part scrutinized, racism, grotesque, but still has the moral of the story. This contradiction made this animation loveable (Garisson, 2001). The PG-rated animation is growing until now and it was always giving one message; simple animation techniques, but greater story. The examples are Beavis and Butthead, South Park, Futurama, and the other new fame, Family Guy and American Dad created by Seth Mcfarlane.

Family Guy is the new popular animation from similar concept, similar market and similar character drawing and the uses of technology. It is still using the conventional method, Two Dimensional Imagery although the trend of Three Dimensional Imagery is inevitable. This television series has won lots of award held in United State of America such as Emmy Award, Daytime Emmy Award, BAFTA Award, and specialized for television animation program, the Annie Award.

But does all the great animation program are the two dimensional, the answer is no. There are some animation that stands out were using the three dimensional technology. The one who has won the highest achievement in Annie Award is the Penguin of Madagascar. Created based from the full length movie Madagascar, the penguins were stealing the silver screen because of their uniqueness. In some sequence they were become funnier than the main character in Madagascar. This made them being solo to appear in their own television program. This animation is become something different because of its package. Three creative yet undermine penguins must share a zoo lot with the narcissistic and egocentric lemur called King Julien. This formula is shaping up some endless story telling that will entertain every child in around the world.

Other region aside from Northern America, Europe and United Kingdom also have a great animation program with a great story. England have its Wallace and Gromit phenomena, and Spain has its Pocoyo phenomena. Wallace and Gromit became very popular in England by the year 1999, because of its creator, Peter Lord, graduating from his college is wanted to having his own animation program. He uses the stop motion technique and use the voice of famous local radio announcer, Peter Sallis. The formula is success because of its twisting story. Wallace is having a dog, not just an ordinary dog, but the smarter dog we may ever know. Both of them are an inventor. This is was every children dream to become a scientist, not the formal one but rather more fun scientist. The success was inevitable even until their inside advertising was having a big success as well. Wensleydale Cheese have to postpone their factory closing after their promotion their product in the short animation of 
Wallace and Gromit. People suddenly noticed and follow what Wallace eat and wear in the animation. After this success, the Ardman studio created the full length movie and had won the Academy Award.

Pocoyo is another success story from Spain, although the fame is worldwide until the voice of narrator is play by the famous British novelist, Stephen Fry. They use the Three Dimensional imagery but with smart concept. It using minimum environment, minimun texture and minimum polygon because their main target market is children under 10 years. This concept was become successful because the main attention is aimed proportionally not to the techniques its use, but for their main character. Children, in this group of age, tend to like some sudden action, physical humor, interaction with everyday things such as tools around the house, animals, interesting places like hospital, amusement park (Wright, 2005). This group of age are simply likes the animation because it made them laugh.

Back to the Asian region, there are some examples that if we compare the popularity, America and Europe region are incomparable. Asia, especially Japan with its anime has more greater effect to every person worldwide. Japan produce uncountable great animation with great story. Way back to the golden age are with Astroboy until the millennium era with Onepiece. But the most popular anime from Japan that everyone would agree is the Akira Toriyama's Dragon Ball. Dragon Ball is not just famous in its own country, not just in Asian region but all over the world. Every children in Northern America were noticing this animation program is somewhat popular even though they never seen it on the television. They just touch the animation by its DVD distribution. But the distribution is kept growing for over than 15 years because the demand is never decreasing (Fukunaga, 2009). The more interesting topic we should discuss is, Japan anime is almost never use the Three Dimensional technology to create its animation. Most of the famous animations are only use the 3D just for backing up some sequence that difficult to create by using only drawing frame by frame. For example, the full length movie of Gundam unicorn: episode one. This animation franchise is always use the conventional method, the two dimensional imagery. But for the last sequence, where the Gundam robot re-forming to become a Gundam unicorn, it has to use the three dimensional techniques. This technique was only use simply because to cut the working hour, but the rendering still with the look of two dimensional image. This is another prove that techniques are one of the main key or sometimes become the supporting key to support the story.

Another masterpiece that we should not forget if we talking about great animator from Japan. The name is Hayao Miyazaki. The creation is almost flawless and never stopped to talk about. From its early popularity from My Neighbor Totoro to the most daring storyteller Princess Mononoke. From the Oscar winning full length animation Spirited Away to the latest installment cute but elegant Ponyo. Hayao Miyazaki is not just giving some game changing in Japan's anime industry but already inspired creative people all over the world. We were forbid to talk about the technical term if we talk about Hayao Miyazaki's artwork. The technicality is undeniable. Although he and his team is still using the two dimensional imagery, the creation is stunning because he is not just maximized the uses of the technology, but he also using some mix media, whether he use some manual painting or more modern technique, the three dimensional imagery. But it will be more profound if we discuss deeper about what kind of things he want to tell in every movie he made.

Hayao Miyazaki creation has a marvelous story. It has a deep plot, strong culture and surroundings background, great character's conflict and twist, and always has what animation should have, a moral message. But to be more interesting, people are not attracted by its story just because of its action, its multilevel conflicted drama, or its twisty ending. But people like it because it has honesty. Most of the story tell something that related to us, something that creating some deep connection. "Many people of my generation see the miners as a symbol; a dying breed of fighting men. Now they are gone" (Miyazaki in Odell \& Le Blanc, 2009). Other great example is My Neighbor Totoro. At a first pitch to the investor, this project is almost been canceled because it has no real conflict or action. But after a long engagement to create this project and finally hit the television and 
movie, this animation became unforgettable. The simplicity yet deeper story behind it is the right formula to make it became successful. It tells about naturalism and wonder, about what the main character living her daily life having a connection to the audience. The interaction between characters and their environment, the rural area, is reminded the audience about their childhood. This formula of story made this animation very popular. It became a standard of success at that time when another animation movie released.

Finally, the trend in our country, Indonesia. Although we do not have our own great animation title, but the imported animation have been made some footprints in our local animation history. From the late 80's with the Doraemon, continued to the mid 90's with the Crayon Sinchan, until to the late 2010 with the Upin and Ipin. Doraemon is the first successful story in Indonesia after the private sector has been granted to aired their television program. Doraemon which notably has been popular in its country, Japan, long before it came to Indonesia, was continuing its popularity in Indonesia. One simple concept will rule the children such as in this great animation. Doraemon probably one of the first pioneer about engaging children to actualized their dream by creating a unique cute robot called Doraemon who can grant their imagination just by picking up some high tech device from its pocket. This formula creates some comedies, intrigue, and adhere feeling from the children. Its dream granted device for the lazy Nobita creates a connection with their daily life, which most of the children is living some playful but sometimes forgot what kind of responsibility they might have. These moral lessons attached so deeply to the children that makes this animation became very popular not just in Japan and internationally, but to Indonesian children as well. Until today, the full length movie is still making children queuing in every movie theaters.

Latest phenomena that still been talked by people is the animation from our neighbor country Malaysia, Upin and Ipin. This animation has become very popular in Indonesia because its story is about daily life of school children in Malaysia, whereas is very similar to what children in Indonesia might have. What have they done in Ramadan month, having a fasting, praying five times daily is a great formula to become memorable to almost every children in Indonesia whose majority is a Muslim. No one will ever comparing their three dimensional imagery with other best practice such as Pixar's animation, but people only watching it because of its originality. People adore it because what story formula it has.

\section{CONCLUSION}

As an author, I am not aside the important of the creation itself. What kind of technology we will use is very important because we as an animator will be giving some visual experience to the audience. Visual is why the animation is being watched by the audience from time to time. Furthermore, sometimes visual is being more worship because the technology was developing to become more dramatic than ever. Latest software that has been used for creating three-dimensional imagery has some stunning evolution. Consequently, some people were forgetting the other factor that is the most important to produce some animation. People were forgetting that the key power to create some great animation is the story. There are many great examples to support this statement. From the endless humor that Road Runner and Wild E. Coyote gave to the latest hilarious that Upin and Ipin have. Hopefully, in the future, there will be more animation produced from Indonesian. From this installment, supposedly it must have been an unforgettable creation. To be an unforgettable work, it must have a great story. 


\section{REFFERENCES}

Edwards, G. (November, 2010). The wonder boys. Wired Magazine, p. 138.

Fukunaga, G. (December, 2008). From Dragon Ball Z to eternity. Animation Magazine, p. 42.

Garrison, E. (2001). A reflection of society and a message on family. Retrieved on January 30, 2011, from http://www.snpp.com/other/papers/eg.paper.html

Odell, C., \& Le Blanc, M. (2009) Studio Ghibli: The films of Hayao Miyazaki and Isao Tahata. Somerset: J.F. Print.

Wright, J. A. (2005) Animation writing and development: From script development to pitch. Oxford: Focal Press. 